\title{
PERUBAHAN AKTIVITAS NELAYAN DI URK, PROVINSI FLEVOLAND SETELAH PEMBANGUNAN AFSLUITDIJK
}

\author{
Shasa Chairunnisa ${ }^{a}{ }^{*}$, Dewi Susiloningtyasa ${ }^{a}$, Tuty Handayania ${ }^{\text {, Titin Siswantining }}{ }^{\mathrm{b}}$ \\ ${ }^{a}$ Marine Science Master Program, Faculty of Mathematics and Natural Science, \\ University of Indonesia, Depok, Indonesia \\ ${ }^{b}$ Department of Mathematics, Faculty of Mathematics and Natural Science, \\ University of Indonesia, Depok, Indonesia \\ *Koresponden penulis : shasa.chairunnisa@gmail.com
}

\begin{abstract}
Abstrak
Afsluitdijk adalah tanggul laut terbesar yang dibangun oleh pemerintah untuk mengatasi masalah banjir di Belanda. Pembangunan Afsluitdijk menyebabkan beberapa perubahan pada lingkungan dan komunitas pesisir di sekitarnya, salah satunya adalah komunitas nelayan di Urk, Provinsi Flevoland, Belanda. Tujuan dari penelitian ini adalah untuk menganalisis perubahan kegiatan penangkapan ikan setelah pembangunan Afsluitdijk. Penelitian ini dilakukan di Desa Urk, Provinsi Flevoland, Belanda pada Mei - Juni 2019. Penelitian ini menggunakan pendekatan deskriptif kualitatif. Data penelitian diperoleh dari wawancara mendalam dan studi literatur. Hasil penelitian menunjukkan adanya perubahan lingkungan akuatik yang awalnya merupakan air asin menjadi air tawar, hal ini membuat nelayan harus beradaptasi dengan kondisi baru. Terdapat beberapa nelayan yang masih bertahan hidup untuk menangkap ikan di perairan sekitar Urk dan Harlingen setelah pembangunan, tetapi ada juga yang beralih profesi dan pindah ke daerah lain di Belanda. Kesimpulan dari penelitian ini adalah terdapat perubahan pada kondisi lingkungan perairan dan ekonomi nelayan, serta nelayan harus beradaptasi dengan kondisi baru setelah pembangunan Afsluitdijk. Hasil penelitian ini diharapkan dapat digunakan sebagai referensi oleh peneliti dan pemerintah dalam membuat kebijakan terkait pembangunan tanggul laut di Teluk Jakarta.
\end{abstract}

Kata Kunci: Afsluitdijk, Lingkungan perairan, Nelayan, Tanggul laut, Urk

\begin{abstract}
Afsluitdijk is the biggest sea dike built by the government to overcome the problem of flooding in the Netherlands. The construction of Afsluitdijk caused several changes to the environment and the surrounding coastal communities, one of them was the fisherman community in Urk, Flevoland Province, The Netherland. The purpose of this study is to analyze the changes in fishing activities after the construction of Afsluitdijk. This research was conducted in Urk Village, Flevoland Province, The Netherlands in May June 2019. This research used a qualitative descriptive approach. Research data obtained from in-depth interviews and literature studies. The results of this research are there were changes in the aquatic environment that were originally salt water into freshwater, this makes fishermen must adapt to the new conditions. There were some fishermen who still survive to catch fish in Urk and Harlingen after the construction, but there were also those who switch professions and moved to other areas in the Netherlands. The conclusion of this research is there were changes in the aquatic environment, economic fishermen, and made fishermen must adapt after the construction of Afsluitdijk. The results of this study are expected to be used as a reference by researchers and the government in making policies related to the construction of a sea dike in Jakarta Bay.
\end{abstract}

Keywords: Afsluitdijk, Aquatic Environment, Fishermen, Sea dike, Urk

\section{PENDAHULUAN}

Belanda telah lama dikenal sebagai negara yang daratannya berada di bawah permukaan air laut. Beberapa wilayahnya bahkan mencapai 6,67 $\mathrm{m}$ di bawah permukaan laut. Menurut Bos dan Zwaneveld [1], dua pertiga daratan di Belanda rentan terhadap banjir. Kondisi ini memberikan kerugian besar bagi negara karena banyak permukiman dan 
fasilitas jalan yang mengalami kerusakan. Menurut Deltares [2], dampak dari rendahnya daratan ini adalah meningkatnya risiko banjir, kerusakan bangunan dan infrastruktur seperti jalan, jembatan dan tanggul. Selain banjir, masalah lain di Belanda, khususnya Belanda bagian Utara pada 1900-an adalah adanya badai pada musim-musim tertentu. Salah satu badai terbesar yang pernah ada di Belanda adalah badai pada tahun 1916. Badai tersebut menghancurkan pemukiman disekitar pesisir, menghancurkan lahan pertanian, merendam pemukiman masyarakat, dan menyebabkan ribuan orang meninggal [3].

Pada tahun 1891, salah satu insinyur Belanda bernama Cornelis Lely yang pada saat itu menjabat sebagai Menteri Transportasi dan Pekerjaan Umum Belanda mengusulkan proyek bernama Zuiderzee Works. Zuiderzee Works yang dibangun pada awal abad ke-20 meliputi pembangunan bendungan, penghalang gelombang badai, pintu air, dan tanggul [3]. Salah satunya adalah pembangunan tanggul lepas pantai yang disebut Afsluitdjk (Enclosure Dike). Proyek ini diusulkan sebagai solusi permasalahan banjir di Belanda. Awalnya proposal proyek yang diajukan Lely ditolak, tetapi pada tanggal 13-14 Januari 1916, tanggul di sepanjang Zuiderzee hancur akibat badai musim dingin yang bertepatan dengan tingginya debit dari sungai menuju Zuiderzee, sehingga memicu terimplementasinya rencana Zuiderzee Works [4]. Selain itu, kekurangan makanan yang mengancam selama Perang Dunia I menambah keyakinan pemerintah untuk melaksanakan proyek tersebut. Akhirnya pada 14 Juni 1918, Undang-Undang Zuiderzee disetujui. UU Zuiderzee dibuat dengan tiga tujuan utama yaitu melindungi Belanda dari ombak dan badai besar dari Laut Utara (North Sea); meningkatkan pasokan makanan untuk penduduk Belanda dengan cara mengembangkan dan mengolah lahan pertanian baru; dan meningkatkan pengelolaan air dengan menciptakan danau air tawar dari cerukan air garam yang tidak terkontrol. Proyek ini dimulai dengan pembangunan Afsluitdijk pada tahun 1927 hingga 1932 dari wilayah Den Oever, Provinsi Belanda Utara sampai ke Desa Zurich, Provinsi Friesland.

Pembangunan Afsluitdijk mulai dari perencanaan hingga pengembangan banyak menuai pro dan kontra dari berbagai pihak. Banyak peneliti berasumsi bahwa pembangunan tanggul laut akan mempengaruhi kondisi ekologis dan sosial masyarakat pesisir di sekitarnya. Selain itu, banyak masyarakat yang menggantungkan hidupnya pada sumber daya perikanan di sekitar Laut Utara. Terdapat beberapa desa nelayan yang akan terdampak seperti Volendam, Urk, Bunschoten, Spakenburg, dan Lemmer. Berdasarkan pro dan kontra tersebut, pemerintah dan masyarakat mengadakan diskusi untuk membahas dan mencari solusi terbaik. Hasil diskusi menyatakan bahwa Afsluitdijk tetap akan dibangun karena tanggul ini dianggap sangat penting untuk keselamatan semua warga negara Belanda di masa depan.

Setelah Afsluitdijk dibangun, kegiatan perikanan di sekitar Zuiderzee mulai mengalami perubahan, begitupun dengan kegiatan perikanan di Urk. Terlepas dari perubahan kondisi perairan di sekitarnya, masyarakat Urk dapat beradaptasi dengan baik sehingga dapat mempertahankan identitasnya sebagai desa nelayan. Tujuan dari penelitian ini adalah untuk mengetahui perubahan kegiatan perikanan dan mengetahui pola adaptasi nelayan di Desa Urk, sehingga masyarakat perikanan Urk dapat menjadi contoh bagi negara-negara lain yang memiliki permasalahan yang sama, salah satunya untuk pemerintah Indonesia yang saat ini berencana untuk membangun tanggul laut di sepanjang Teluk Jakarta. Hasil penelitian ini diharapkan dapat digunakan sebagai referensi oleh peneliti dan pemerintah dalam membuat kebijakan terkait pembangunan tanggul laut di Teluk Jakarta.

\section{MATERI DAN METODE}

Penelitian ini dilakukan pada bulan Mei Juli 2019 di Urk, Provinsi Flevoland, Belanda. Lokasi penelitian dipilih secara purposif dengan pertimbangan bahwa Urk adalah salah satu desa yang dapat mempertahankan identitasnya sebagai desa nelayan meskipun terkena dampak pembangunan Afsluitdijk. Penelitian ini menggunakan pendekatan deskriptif kualitatif mengenai perubahan kegiatan penangkapan ikan di Urk setelah pembangunan Afsluitdijk. Penelitian kualitatif adalah bentuk tindakan sosial yang 
menekankan pada cara orang menafsirkan, dan memahami pengalaman mereka untuk memahami realitas sosial individu. Penelitian ini menggunakan wawancara, buku harian, jurnal, observasi, dan kuesioner terbuka untuk mendapatkan, menganalisis, dan menginterpretasikan data dari bahan visual dan tekstual, dan sejarah lisan [5]. Data dikumpulkan berdasarkan jurnal dan wawancara mendalam dengan salah satu penduduk Urk (inisial OR) yang terkena dampak dan salah satu pegawai Gementee Urk yang juga merupakan penduduk asli Urk (inisial BJ). Kedua responden dipilih secara snowball sampling. Responden adalah mereka yang mengetahui bagaimana sejarah Afsluitdijk dan perubahan yang terjadi pada aktivitas perikanan di Urk. Menurut Umar [6], snowball sampling adalah teknik untuk menentukan sampel pada awalnya dalam jumlah kecil, kemudian semakin besar sampai data yang diinginkan terpenuhi.

Data dari wawancara dianalisis secara kualitatif. Hasil analisis dieksplorasi secara interaktif. Data yang telah diperoleh dan dikumpulkan dari lapangan dirangkum dengan memilih poin utama, berfokus pada hal-hal penting, dan mencari tema dan pola. Pengurangan data dapat memberikan informasi yang lebih jelas dan membuatnya lebih mudah untuk menemukan data lebih lanjut jika masih diperlukan. Selanjutnya, data disajikan secara deskriptif untuk memudahkan memahami makna data berdasarkan persepsi dan diperkuat dengan literatur terkait. Setelah data dikurangi dan disajikan, kemudian dibuat kesimpulan. Lokasi Urk dapat dilihat pada Gambar 1.

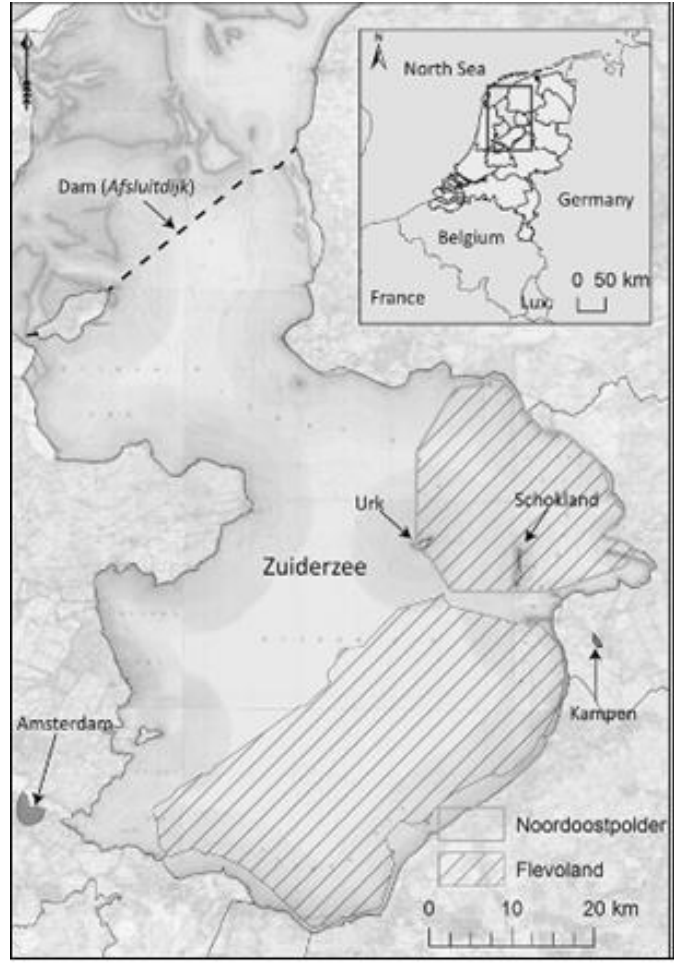

Gambar 1. Lokasi Urk dan Afsluitdijk (Sumber: [3])

Gambar 1 merupakan peta geografis negara Belanda bagian Utara pada tahun 1832. Wilayah yang diarsir (bergaris) saat ini dikenal sebagai Provinsi Flevoland. Provinsi ini merupakan pulau buatan yang dibangun pada tahun 1955. Terlihat pada peta bahwa awalnya Urk merupakan pulau terpencil di tengah perairan. Namun setelah adanya pulau buatan, Urk tidak lagi berdiri sendirian.

\section{HASIL DAN PEMBAHASAN}

\section{Sejarah Afsluitdijk}

Afsluitdijk (Enclosure Dam) adalah salah satu tanggul terbesar dan popular di Belanda. Tanggul ini dibangun pada tahun 1927, setelah UU Zuiderzee diterima pada tahun 1918. Pada saat itu pemerintah menyediakan dana keuangan untuk menyusun rencana dalam rangka melindungi Belanda dari banjir dan menciptakan lahan pertanian untuk kebutuhan pangan saat masa Perang Dunia I. Menurut Dastgheib dan Roelvink [7], tanggul laut di dataran rendah berfungsi untuk melindungi ceruk pasang surut, sungai dan muara dari gelombang laut. Pemerintah membentuk De Dienst der Zuiderzeewerken (Departemen Pekerjaan Zuiderzee) yang 
bertugas mengawasi konstruksi dan manajemen awal konstruksi Afsluitdijk. Sebelum Afsluitdijk dibangun, pemerintah Belanda melakukan uji coba terlebih dahulu dengan membangun tanggul bernama Amsteldiepdijk sepanjang 2,5 km di seberang Amsteldiep [4]. Setelah Amsteldiepdijk selesai dibangun dan dianggap efektif, pemerintah mulai membangun Afsluitdijk. Afsluitdijk dibangun dari 4 titik geografis yaitu Den Oever, Zurich dan dua stasiun pekerja konstruksi di Breezand-Afsluitdijk dan Kornwerderzand. Perbedaan konstruksi Afsluitdijk pada tahun 1900an dan saat ini disajikan pada Gambar 2.

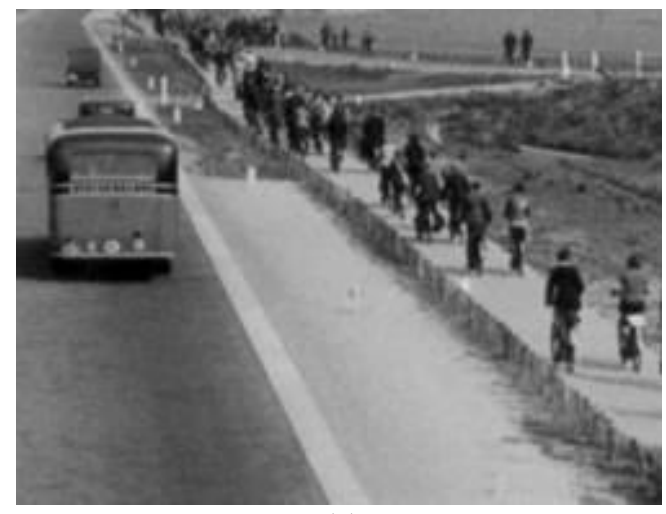

(a)

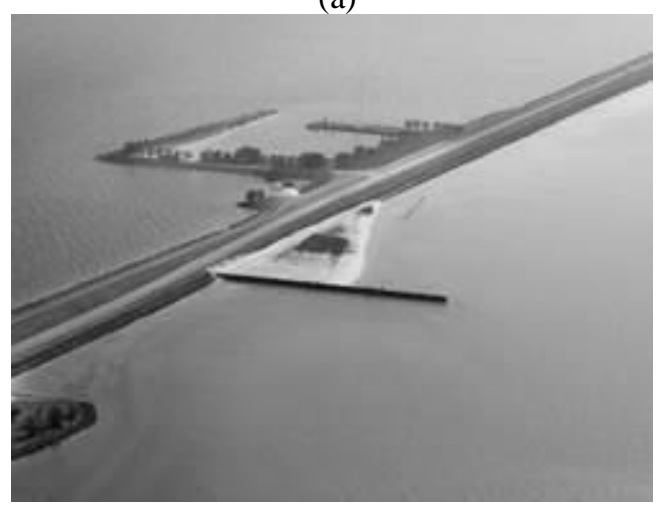

(b)

Gambar 2. 1927 (a) dan 2019 (b) Afsluitdijk (Sumber: [8])

Tujuan utama pembangunan Afsluitdijk adalah untuk mencegah banjir akibat badai dari Laut Utara yang sejak tahun 1200 sudah sering terjadi di Belanda dan menyebabkan kerugian. Dengan tanggul ini, penduduk Belanda, terutama orang-orang yang tinggal di sekitar Zuiderzee akan aman dari badai dan banjir. Tanggul sepanjang $32 \mathrm{~km}$ ini dapat digunakan sebagai jalur lalu lintas dari Den Oever di Provinsi Belanda Utara menuju Desa Zurich di Provinsi Friesland [9]. Tanggul ini memiliki lebar $90 \mathrm{~m}$ dan ketinggian 7,29 $\mathrm{m}$ di atas permukaan laut [10]. Sejak pembangunan Afsluitdijk dan proyek tanggul lainnya, Belanda mulai dikenal sebagai negara yang mahir dalam menangani permasalahan banjir dan pengelolaan air. Sejarah Afsluitdijk dapat dilihat pada Gambar 3.

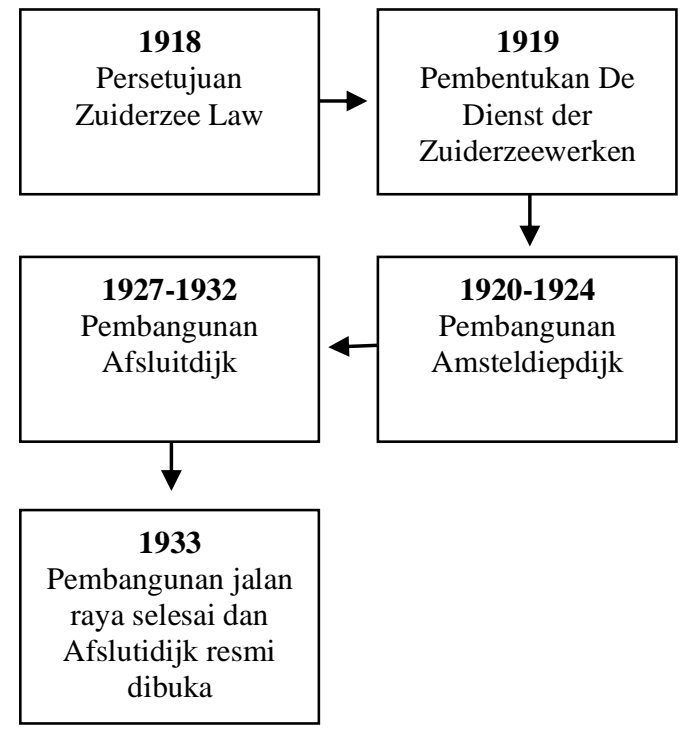

Gambar 3. Sejarah Pembangunan Afsluitdijk

\section{Masyarakat Urk}

Urk adalah sebuah wilayah yang terletak di Provinsi Flevoland, Belanda dengan koordinat $52^{\circ} \quad 40^{\prime} \mathrm{N} \quad 5^{\circ} 36^{\prime} \mathrm{E}$. Total luas wilayah Urk adalah $109,90 \mathrm{~km}^{2}$, terdiri dari $11,54 \mathrm{~km}^{2}$ permukaan tanah dan $98,37 \mathrm{~km}^{2}$ permukaan air [11]. Menurut data Regionale Kerncijfers Nederland pada tahun 2019, total populasi Urk adalah sebanyak 20.776 orang yang terbagi menjadi 10.520 pria dan 10.256 wanita. Saat ini Urk adalah bagian dari Provinsi Flevoland, tetapi sebelumnya Urk adalah sebuah pulau kecil di tengah Zuiderzee dengan luas 80 hektar. Perubahan ini terjadi ketika reklamasi lahan [12]. Sebelum Afsluitdijk dibangun, penduduk Urk dan komunitas pesisir lainnya mengeluhkan intensitas banjir yang tinggi, sehingga tanah mereka untuk pertanian tersapu banjir, permukiman terendam banjir, dan ribuan nelayan meninggal ketika sedang melaut [3].

Sebelum Afsluitdijk dibangun, sebagian besar masyarakat Urk bekerja di sektor perikanan, yaitu sebagai nelayan dan pengolah ikan. Nelayan Urk sangat bergantung dengan 
sumber daya perikanan di perairan sekitarnya. Setelah Afsluitdijk dibangun, perairan di sekitar Urk yang dulunya air asin berangsurangsur berubah menjadi air tawar. Konstruksi Afsluitdijk yang menutup Zuiderzee dari Laut Utara membuat danau air tawar yang disebut Danau Ijssel (Ijsselmeer). Setelah kondisi perairan di sekitar mereka berubah, nelayan Urk terus bertahan memancing dan sampai sekarang telah menjadi pusat perikanan yang cukup besar di Belanda Utara. Tidak hanya unggul di sektor perikanan, beberapa penduduk Urk juga bekerja di sektor Pertanian, Kehutanan, Industri dan Energi, Perdagangan dan Perhotelan, Informasi Transportasi dan Komunikasi, Layanan Keuangan dan Real Estat, Layanan Bisnis, dan Rekreasi Budaya.

Penduduk Urk adalah salah satu komunitas yang unik di Belanda. Saat ini mereka masih menggunakan salah satu dialek tertua di Belanda dalam melakukan percakapan sehari-hari. Penduduk Urk yang sebagian besar beragama Protestan juga sangat taat dalam menjalankan agamanya. Penduduk Urk yang bekerja sebagai nelayan tidak akan melakukan penangkapan ikan pada hari Minggu, karena pada hari itu mereka akan pergi beribadah ke gereja.

\section{Perubahan Kondisi Perairan}

Konstruksi Afsluitdijk yang membentang panjang dari Den Oever sampai Zurich menutup air yang mengalir dari laut ke perairan di sekitar Urk. Akibatnya, air tawar yang mengalir dari sungai tidak dapat terbuang ke laut lepas dan menyebabkan air di sekitar Urk berubah menjadi air tawar (Danau Ijssel). Wilayah perairan yang berubah menjadi Danau Ijssel memiliki luas $3.500 \mathrm{~km}^{2}$ dengan kedalaman air 3,4 m. Salinitas air juga mengalami perubahan setelah adanya tanggul laut. Sebelumnya salinitas mencapai 30\% di dekat Laut Wadden (Wadden sea), 11\% di Urk, dan kurang dari $0,5 \%$ di dekat muara sungai. Namun, setelah Afsluitdijk dibangun, salinitas menurun tajam menjadi $3 \%$ pada tahun 1932 dan menurun lagi menjadi $0,16 \%$ pada tahun 1937 [13]. Ilustrasi perubahan tipe perairan di Zuiderzee tersaji pada Gambar 4.

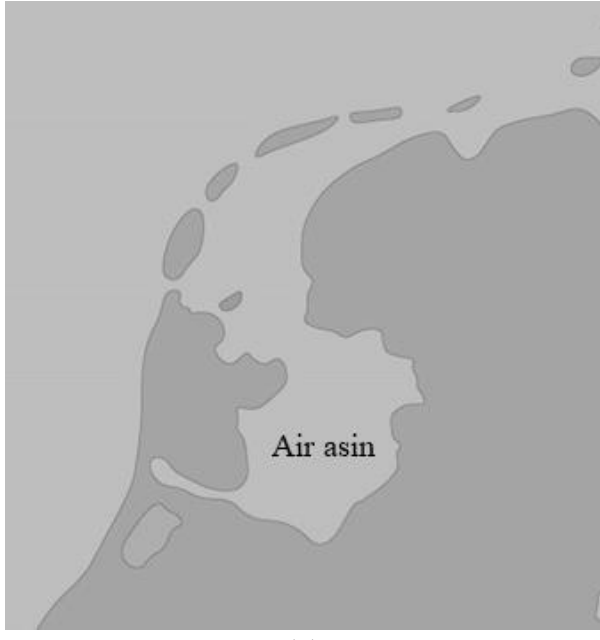

(a)

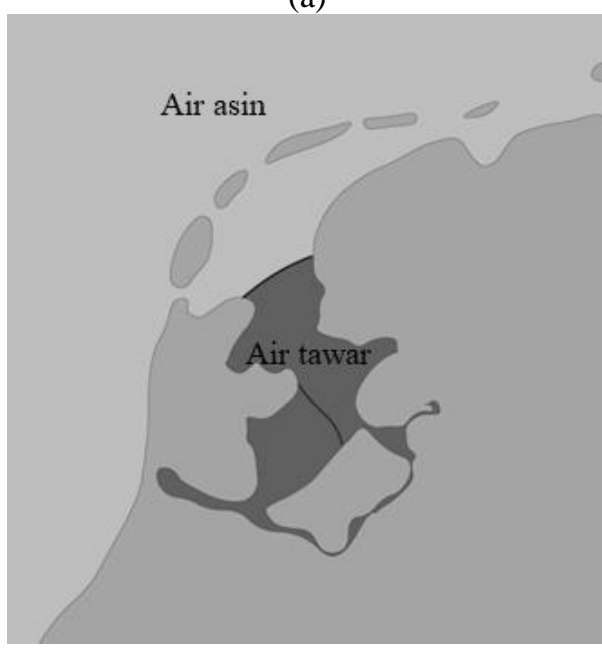

(b)

Gambar 4. Ilustrasi tipe perairan di sekitar Urk sebelum (a) dan setelah (b) pembangunan Afsluitdijk.

Penutupan Laut Utara oleh Afsluitdijk menyebabkan banyak perubahan pada perairan di sekitar Urk. Setelah beberapa tahun, air garam berubah menjadi air payau dan kemudian berubah menjadi air tawar. Karena perubahan kondisi air, biota di dalam air juga berubah. Spesies ikan asli seperti Zuiderzee Herring (Clupea harengus), Ikan Teri (Engraulis encrasicholus), Smelt (Osmerus eperlanus), Flounder (Pleuronectus flesus L.), Udang (Crangon crangon, Leander longirostris, varian Palaemonetes) dan beberapa spesies anadromromus lainnya mulai menghilang. Setelah Zuiderzee ditutup, spesies ikan baru muncul di Danau Ijssel, yaitu Pike-perch (Stizostedon lucioperca L.), Bertengger (Perca fluviatilis L.), Bream (Abramth brama L.), Roach (Rutilus rutilus L.), dan Belut (Anguilla anguilla) [13]. 
Meningkatnya Belut dan Pike-perch dimanfaatkan oleh nelayan sebagai target utama tangkapan dan membantu meningkatkan perekonomian nelayan Urk yang masih ingin menangkap ikan di Danau Ijssel.

Setelah penggantian air asin menjadi air tawar, populasi Smelt (Osmerus eperlanus) yang awalnya berlimpah di muara Zuiderzee berangsur-angsur berkurang karena sulit untuk bermigrasi. Meskipun pemerintah Belanda membuka pintu air Afsluitdijk secara teratur, ternyata tetap tidak membantu Smelt dalam bermigrasi, sehingga peluang hidupnya kecil. Awalnya smelt bisa tumbuh hingga ukuran 25 $\mathrm{cm}$ dan menjadi dewasa dalam 3-4 tahun. Namun, karena perubahan kondisi air dan sulitnya bermigrasi, pertumbuhan Smelt hanya terbatas pada ukuran $10-12 \mathrm{~cm}$ dan matang hanya dalam satu tahun. Selain itu, Smelt yang terperangkap di Danau Ijssel hanya akan melakukan pemijahan sebanyak 1 kali [14]. Kemudian spesies ikan lain seperti Herring (Clupea harengus), Ikan Teri (Engraulis encrasicolus), dan lumba-lumba yang mati karena terperangkap di danau mulai membusuk dan memberi bau tidak sedap kepada warga Urk.

\section{Perubahan Ekonomi Nelayan}

Setiap perkembangan pasti akan berdampak pada kegiatan dan pendapatan masyarakat sekitar. Terutama pengembangan wilayah pesisir di mana umumnya banyak orang menggantungkan hidupnya pada sumber daya laut. Berdasarkan wawancara, pembangunan Afsluitdijk mengubah sebagian mata pencaharian masyarakat pesisir di sekitarnya. Di Urk, pada awal 1850-1927, sebagian besar orang bekerja sebagai nelayan dan hidup dari sumber daya laut. Mereka melakukan penangkapan ikan skala kecil di sekitar pantai dengan pukat sebagai alat pancing yang paling dominan. Pada saat itu situasi ekonomi nelayan Urk masih di bawah rata-rata dibandingkan dengan wilayah Belanda lainnya. Ini mungkin karena posisi pulau Urk yang berdiri sendiri di tengahtengah Zuiderzee. Interaksi dengan daerah lain cukup sulit pada waktu itu sehingga nilai jual beli rendah. Pada tahun 1932 ketika perairan dari Laut Utara ditutupi oleh Afsluitdijk, sebagian besar nelayan yang bergantung pada perikanan merasa sulit untuk menangkap ikan. Tetapi sampai sekarang Urk dapat bertahan dan bahkan berkembang di bidang perikanan. Beberapa nelayan pindah ke Harlingen untuk terus memancing di air asin, beberapa masih menangkap ikan di air tawar (Danau Ijssel), dan beberapa berhenti memancing dan berganti profesi sebagai pekerja konstruksi. Tidak lama setelah Afsluitdijk selesai, reklamasi tanah dilakukan di perairan sekitar Urk. Sejak itu kondisi ekonomi komunitas Urk telah membaik. Berdasarkan hasil wawancara, komunitas Urk hanya mengalami kesulitan pada awal pembangunan Afsluitdijk. Sejak 1950 kegiatan penangkapan ikan di Urk mulai mengalami pertumbuhan yang cukup baik dan produksi ikan terus meningkat setiap tahun. Pada akhirnya ini berdampak baik pada kondisi ekonomi mereka sampai dengan saat ini.

\section{Adaptasi Nelayan}

Afsluitdijk membuat masyarakat Urk khawatir tentang kondisi ekonomi mereka karena kehidupan mereka bergantung pada laut. Pada tahun 1930, dua tahun sebelum penutupan lubang terakhir Afsluitdijk, para nelayan di sekitar Zuiderzee datang ke Den Haag (Ibu Kota Belanda) untuk menyampaikan keluhan mereka kepada pemerintah. Keluhan mereka didengar oleh pemerintah tetapi masih tidak mengubah keputusan pemerintah untuk membangun Afsluitdijk. Pemerintah terus mengembangkan Afsluitdijk karena mereka berpikir untuk jangka waktu yang panjang dan merasa bahwa Afsluitdijk sangat penting untuk melindungi Belanda dari banjir dan badai. Sebagai imbalannya, pemerintah memberikan kompensasi kepada nelayan di sekitar Zuiderzee yang mencakup uang untuk nelayan tua, pendidikan gratis untuk anak-anak nelayan, pinjaman bagi nelayan untuk memulai bisnis baru, dan memberikan lisensi baru untuk melakukan penangkapan di Danau Ijssel [15]. Hal ini sesuai dengan penuturan BJ. Penutupan itu akhirnya memaksa para nelayan untuk beradaptasi dengan kondisi baru. Setelah pembangunan Afsluitdijk selesai dan mengubah air di sekitar mereka menjadi air tawar, komunitas Urk, terutama nelayan, mulai beradaptasi. Pola adaptasi nelayan Urk 
dalam penelitian ini dapat dilihat pada Gambar 5.

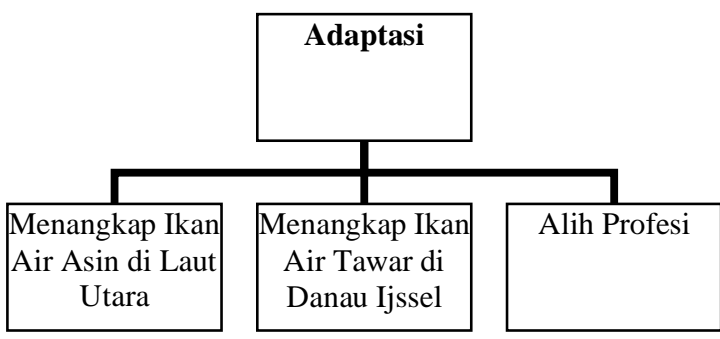

Gambar 5. Tiga tipe adaptasi nelayan Urk setelah pembangunan Afsluitdijk

Pola adaptasi nelayan Urk dalam penelitian ini dibagi menjadi tiga, yaitu:

1. Menangkap Ikan Air Asin di Laut Utara

BJ mengatakan bahwa setelah air di sekitar Urk berubah menjadi air tawar, beberapa nelayan membuat kelompok/grup kecil untuk bekerja bersama membuat kapal penangkap ikan yang lebih besar dan memancing di Laut Utara (di luar Danau Ijssel). Beberapa dari mereka pindah ke Harlingen, tetapi beberapa tetap di Urk. Hasil wawancara ini sesuai dengan penelitian [3] yang menyatakan bahwa setelah air berubah menjadi air tawar, penduduk Urk masih aktif di sektor perikanan di Laut Utara. Hasil tangkapan yang mereka dapatkan di Laut Utara, mereka bawa ke Urk untuk dijual. Pada saat itu, Urk adalah salah satu pusat pemasaran ikan terbesar di Belanda [16].

\section{Menangkap Ikan Air Tawar di Danau Ijssel}

Meskipun beberapa nelayan memutuskan untuk pindah ke Harlingen dan melakukan penangkapan ikan di Laut Utara, beberapa nelayan lain memilih untuk tinggal di Urk [11]. Nelayan jenis ini umumnya adalah nelayan yang memiliki modal terbatas untuk membuat kapal besar dan tidak ingin menghabiskan biaya operasional yang lebih tinggi. Menurut Norie et al. [17] beberapa kapal kecil masih beroperasi di sekitar Urk sedangkan kapal-kapal besar beroperasi di sekitar area pelabuhan. Mereka memilih untuk tetap mencari ikan di pesisir sekitar tempat tinggal mereka, sehingga biaya operasionalnya kecil. Nelayan jenis ini mulai menggunakan Fyke Net dan menangkap berbagai jenis ikan. Fyke net merupakan alat tangkap pasif bergerigi yang menangkap ikan yang berenang secara aktif di sepanjang garis
[18]. Setelah Zuiderzee ditutup, Belut adalah tangkapan utama mereka. Pada awal pembangunan Afsluitdijk Belut belum muncul di perairan sehingga pendapatan nelayan dirasa masih sulit. Namun seiring berjalannya waktu, populasi Belut mulai bertambah dan memberi manfaat bagi nelayan sehingga dapat memenuhi kebutuhan sehari-hari.

\section{Alih Profesi}

Tidak semua nelayan Urk memutuskan untuk terus menangkap ikan, beberapa dari mereka memutuskan untuk berhenti dan mencari pekerjaan lain yang dianggap lebih menjanjikan. Beberapa bekerja di proyek reklamasi pulau, bekerja sebagai pekerja pabrik, bertani, dan mencari pekerjaan di kota-kota lain [4]. Menurut Fauziyah [19], seseorang harus memilih tindakan yang dapat memberikan hasil terbaik sesuai dengan pertimbangannya pribadi.

\section{KESIMPULAN}

Kesimpulan dari penelitian ini adalah pembangunan Afsluitdijk memberi dampak pada perubahan lingkungan akuatik yang awalnya merupakan air asin menjadi air tawar, hal ini membuat nelayan harus beradaptasi dengan kondisi baru. Beberapa nelayan masih bertahan untuk menangkap ikan air tawar di perairan sekitar Urk, beberapa lainnya membuat kelompok kecil untuk bekerja sama menangkap ikan air asin di Laut Utara dengan kapal besar, dan sisanya beralih profesi bahkan pindah ke daerah lain di luar Urk.

\section{UCAPAN TERIMA KASIH}

Penelitian ini didukung oleh Frans Seda Foundation dan Program Hibah PITTA (NKB-0625/ UN2.R3.1 / HKP.05.00 / 2019). Kami juga berterima kasih kepada rekanrekan kami dari Universitas Indonesia dan Universitas Tilburg karena memberikan wawasan, pendapat, dan bantuan sehingga penelitian ini dapat dilakukan dengan benar.

\section{DAFTAR PUSTAKA}

[1] Bos, F., and P. Zwaneveld, "Cost-benefit analysis for flood risk management and water governance in the Netherlands," an 
overview of one century MPRA Paper 80933, pp. 49, 2017.

[2] Deltares, Sinking Cities: an Integrated Approach Towards Solutions, Utrecht: Deltares, pp. 12, 2015.

[3] Popta, Y.T.V., C.L. Westerdahl, and B.G. Duncan, "Maritime Culture in the Netherlands: Accessing The Late Medieval Maritime Cultural Landscapes of The North-Eastern Zuiderzee," International Journal of Nautical Archaelogy, vol. 48, no. 1, pp. $172-$ 188, Maret 2019.

[4] Akker, P.V.D., The Impact of a Breach in The Afsluitdijk on The Probability of Failure of Ijsselmeer Dikes. Master of Science in Civil Engineering, Delft University of Technology, pp. 193, 2014.

[5] Mohajan, H. K. "Qualitative Research v Methodology in Social Sciences and Related Subjects," Journal of Economic Development, Environment and People, vol. 7, issue 01, pp. 23-48, 2018.

[6] Umar, H., Business Research Methods: A Student's Guide to Conducting Research Complete with Examples of Proposals and Research Results in Management and Accounting, Jakarta: Gramedia Pustaka Utama, pp. 336, 2003.

[7] Dastgheib, A., and J.A. Roelvink, "Zuiderzee is now called Ijsselmeer: Process-based Modeling," Jubilee Conference Proceedings, pp. 91-95, 2012.

[8] Rijkswaterstaat Ministerie van Infrastructuur en Milieu (2019). Our History. [Online]. Available: https://www.rijkswaterstaat.nl/

[9] Blanken, M., Force of Order and Methods: An American View into the Dutch Directed Society, Martinus Nijhoff - The Hague: Springer Science \& Business Media, pp. 184, 2012.

[10] Li, Y., P. Arecco, C.M. Eguez, and M.J.R. Fuentes, "Adapting The
Afsluitdijk to Climate Changes," Proceedings of $5^{\text {th }}$ International Technical Conference on Hydraulic Engineering. (CHE V), London: CRC Press, 2018.

[11] European Commission, "Assessment of the status, development and diversification of fisheries-dependent communities. URK Case study report," MRAG Consortium: Socioeconomic dependency case study reports, pp. 33, 2010.

[12] Langbroek, M., and V. Frank, "Learning from The Social Impacts Associated with Initiating a Windfarm Near the Former Island of Urk, The Netherlands," $J$. Impact Assessment and Project Appraisal, vol. 30, no. 2, pp. 167-178, 2012.

[13] Vierssen, W.V., and A.W. Breukelaar, Lake Veluwe, a Macrophyte-dominated System under Eutrophication Stress, The Netherlands: Kluwer Academic Publishers, 1994.

[14] Tulp, I., M. Keller, J. Navez, H.V. Winter, M. de Graaf, and W. Baeyens, "Connectivity between Migrating and Landlocked Populations of a Diadromous Fish Species Investigated Using Otolith Microchemistry," PLoS ONE, vol. 8, no. 7, 2013.

[15] Bergsma, E., From Flood Safety to Spatial Management: Expert Policy Interactions in Dutch and US Flood Governance.

Amsterdam: Springer.International Publishing, pp. 188, 2019.

[16] Guides, R., The Rough Guide to the Netherlands, pp. 368, 2016.

[17] Norie, I. L., Wilson, and The Cruising Association, The Cruising Almanac 2019. England: Cruising Association, pp 96, 2019.

[18] Hartl, D., and S. Greg S. "Fish Behavior When Encountering A Modified Fyke Net At Two Black Hills Reservoirs," 
Proceedings of the South Dakota Academy of Science, vol. 98, 2019.

[19] Fauziyah. "The Preference of Choosing Non-Political Party Organization in the Election (Cse Study: Teman Ahok Members to Jakarta 2017 Regional Head
Election)," Advances in Social Science, Education and Humanities Research, vol. 191, 2018. 